\title{
Physicochemical Characteristics and Heavy Metals Contents in Soils and Cassava Plants from Farmlands along A Major Highway in Delta State, Nigeria
}

\section{*11OSAKWE, STEPHEN ANAPUWA; ${ }^{2}$ OKOLIE, LUCKY PRECIOUS}

\author{
Department of Chemistry, Delta State University, Abraka, Nigeria \\ *Correspondence Authore-mail: saosakwe@gmail.com
}

\begin{abstract}
Soil samples and cassava tubers and leaves collected from farmlands along Agbor-Asaba expressway were analysed for their heavy metal levels in order to assess their levels of contamination on the environment as a result of traffic activities. Physicochemical properties of the soil samples were also determined. The soil $\mathrm{pH}$ had a mean value of $5.15 \pm$ 0.48 indicating that the soils were moderately acidic. Total Organic Carbon and Total Nitrogen mean values were $1.20 \pm 0.13 \%$ and $0.09 \pm 0.80 \%$ respectively showing presence of some organic matters. Electrical conductivity of the soil samples had the mean value of $5.94 \pm$ $1.32 \mu \mathrm{scm}^{-1}$ indicating significant presence of ionisable materials in the soils. Particle size was dominated by sand size fractions followed by clay and then silt which revealed that the soils were coarse and have low supply of nutrients and moisture. The mean levels of heavy metals in the soil samples were $\left(\mathrm{mgkg}^{-1}\right) 142.93 \pm 42.16$ for $\mathrm{Fe}, 59.34 \pm 25.21$ for $\mathrm{Zn}, 14.27 \pm 5.39$ for $\mathrm{Cr}$, $13.63 \pm 5.41$ for $\mathrm{Pb}$ and $24.98+15.57$ for $\mathrm{Ni}$. These metal levels were in the abundance trend of $\mathrm{Fe}>\mathrm{Zn}>\mathrm{Ni}>\mathrm{Cr}>\mathrm{Pb}$. The mean metal concentrations obtained in the cassava leaves and tubers respectively were $\left(\mathrm{mgkg}^{-1}\right) 21.70+3.45$ and $9.62+3.53$ for $\mathrm{Fe}, 4.15+1.01$ and $1.15+$ 0.44 for $\mathrm{Zn}, 5.12 \pm 2.75$ and $0.37 \pm 0.63$ for $\mathrm{Cr}$ and $3.46 \pm 1.58$ for Pb only in leaves. For both the soil and plant samples, the heavy metal levels were significantly higher than the levels obtained in the control sites confirming some heavy metal enrichments in the soils studied. The plant concentration factor values were in the order $\mathrm{Cr}>\mathrm{Pb}>\mathrm{Fe}>\mathrm{Ni}$ showing that chromium was the easiest to migrate among all the metals studied and that all the metals fall into the category showing medium accumulation except for Nickel which fell into the category of elements lacking accumulation. The overall results show that there is some metal enrichments on the soils and cassava plants as a result of automobile emission on the highway. @ JASEM
\end{abstract}

http://dx.doi.org/10.4314/jasem.v19i4.18

KEYWORDS: Heavy metals, pollution, busy expressway, farmland soils, cassava plants.

\section{INTRODUCTION}

Heavy metals are natural components of the earth crust and as a result they are found naturally in soils and rocks with a subsequent range of natural concentrations in soils, sediments, waters and organisms (Hutton and Synmon, 1986). Human activities through industrial, agricultural, traffic, domestic, mining and other anthropogenic processes have contributed to elevated and toxic levels of these metals when compared to those contributed from geogenic or lithorlogical processes (Pam et al 2013).

Traffic associated environmental pollution is one of the most critical or challenging sources, because it is a non point source and vehicular emissions spread beyond the expected distances polluting the air, land and water bodies. Onianwa and Fakayode (2000) reported that automobile exhaust accounts for about $80 \%$ of the air pollution by heavy metals in Nigeria and this was corroborated by Adriano (2001), who stated that automobile emission is perhaps the greatest single source of contamination. Onder et al., (2007) reported high content of heavy metals in urban road side soils and plant samples and attributed it mostly to high density of traffic.
Soil serves as a sink or reservoir for the metal contaminants of the automobile emissions. Some metals like zinc, copper, iron and cadmium are important components of many alloys, wires, tyres and many industrial processes and could be released into the road side soil and plants as a result of mechanical abrasion and wear (Quasem and Kamal, 1999). Since these metals are not biodegradable, they persist and accumulate over a long time in the soils and vegetation resulting to serious environmental pollution (Mtuazi et al, 2015). This calls for an increasing concern because the pollution may eventually result in negative influence on plants, animals and humans through food chain (Mtuazi et al, 2015). The determination of metals in soil and vegetation samples is very important in monitoring environmental pollution (Al-Khashman, 2012).

The main objective of this study was to determine the heavy metals in roadside soils and cassava plants from farms located along a major highway. This will provide knowledge of the distribution of these metals in soils and vegetation and then evaluate the 
environmental impact caused by automobile emission on the surrounding environment.

\section{MATERIALS AND METHODS}

Study Area: The study area is Agbor-Asaba expressway which has relatively very high traffic density along, Benin-Asaba expressway. The highway passes through four local government areas of Delta State, Nigeria.

Roads from different parts of the Northern States and Edo States as well as roads from some parts of Delta State join the highway at Uromi junction in Agbor, thereby increasing the traffic density. It is this part of the Benin-Asaba expressway that links the rest of the country with the South eastern states and the famous Onitsha market through Asaba via Niger bridge.

The towns where samples were collected include. Agbor in Ika South Local Government Area, with geographical coordinates of longitude $6.19^{\circ}$ East and latitude $6.25^{0}$ North.

Onitsha-Ugbo and Issele-Ukwu in Aniocha South Local Government Area, located at longitude $6.28^{0}$ East and latitude $6.19^{0}$ North.

Okpanam in Oshimili North Local Government Area, situated at longitude 6.39 East and latitude $6.14^{0}$ North

Asaba in Oshimili South Local Government Area with the coordinates of longitude $6.73^{\circ}$ East and latitude $6.2^{0}$ North.

Sample Collection: Soil samples and cassava tubers and leaves were collected from farmlands along the expressway in each of the five towns. Cassava (esculenta grantz) was selected for this study because it is the most commonly cultivated food crop and staple food of the inhabitants of the study area. At each town, soil samples were collected from farms along both sides of the highway at depths of $0-15 \mathrm{~cm}$, $15-30 \mathrm{~cm}$ and $30-45 \mathrm{~cm}$ representing top, middle and bottom soils respectively. The soil samples for each depth from both sides of the road, were bulked and properly mixed using coning and quartering method (Ayodele and Gaya,1994) to get a composite or representative sample. Cassava tubers and leaves were also collected from the farms and separately bulked to form composite samples. The farm from where the samples were collected had no history of fertilizer, herbicide and pesticide application or industrial activity. Control samples were also collected in each town from farms far remote from any automobile or industrial activities and free from usage of any fertilizer, pesticide or herbicide.

Sample Preparation: The soil samples were air-dried at room temperature in a well-ventilated laboratory until constant weight. They were ground separately using an acid pre-washed porcelain motar and pestle and then passed through a $2 \mathrm{~mm}$ plastic sieve prior to analysis.

The cassava tubers and leaves were washed thoroughly with distilled water to remove soil materials and possible aerial deposits on the leaves. The tubers were peeled and sliced before they were dried in the oven at $60^{\circ} \mathrm{C}$ separately with the leaves. The dried leaves and tubers were also separately homogenized into powder in a porcelain motar. The powdered samples were stored in clean stopperred sterile bottles (Djingova et al., 1993).

The samples for metal analysis were digested using a mixture of $2 \mathrm{~cm}^{2}$ of $60 \%$ perchloric acid, $15 \mathrm{~cm}^{3}$ of concentrated nitric acid and $1 \mathrm{~cm}^{3}$ of concentrated sulphuric acid (Burrell, 1974).

Sample Analysis: Analysis of physicochemical properties of the soil samples: The soil physicochemical properties were determined using the approved specific standard methods for each of them. Soil $\mathrm{pH}$ was measured in a soil - water ratio of 1:2.5 (Davey and Conyers 1988). Electrical conductivity (EC), total organic carbon (TOC) and total Nitrogen (TN) were determined using the methods described by Chopra and Kanzar, (1988), Nelson and Sommers, (1982), and Bremner, (1965) respectively. Phosphate was analysed using the method of Bray and Kurtz, (1945) as modified by Juo (1979) while soil particle size was determined according to the method of Bouyocous, (1962).

Quality control was assured through three replicate samples, use of reagents of pure analytical grade, reagent blanks and standard reference materials.

Analysis of Heavy Metals: The digested samples were analysed for the metals using atomic absorption spectrophotometer (Perkin Elmer Model A Analyst 2002) fitted with deuterium lamp for background correction.

\section{RESULTS AND DISCUSSION}

Soil physicochemical properties: Table 1 presents the results of the physicochemical properties of the soil samples 
Table 1: Physicochemical properties of the soil samples

\begin{tabular}{|c|c|c|c|c|c|c|c|c|c|}
\hline \multirow{2}{*}{$\begin{array}{c}\text { Sample } \\
\text { site }\end{array}$} & \multirow{2}{*}{$\begin{array}{l}\text { Dept } \\
\text { h } \\
(\mathrm{cm})\end{array}$} & \multirow[t]{2}{*}{ pH } & \multirow[t]{2}{*}{ E.C $(\mu \mathrm{s} / \mathrm{cm})$} & \multirow[t]{2}{*}{ TOC\% } & \multirow[t]{2}{*}{ TON\% } & \multirow{2}{*}{$\begin{array}{l}\mathrm{PO}^{2-}{ }_{4} \\
\left(\mathrm{mgkg}^{-1}\right)\end{array}$} & \multicolumn{3}{|c|}{ Soil Particle size (\%) } \\
\hline & & & & & & & Clay & Silt & Sand \\
\hline & $0-15$ & 5.70 & 7.91 & 2.08 & 0.141 & 10.5 & 3.5 & 1.1 & 95.4 \\
\hline & $14-30$ & 5.50 & 5.15 & 1.09 & 0.081 & 63.35 & 5.3 & 0.7 & 1.0 \\
\hline & $30-45$ & 5.30 & 3.65 & 0.99 & 0.064 & 1.93 & 11.6 & 0.4 & 88.0 \\
\hline \multirow[t]{3}{*}{ B } & $0-15$ & 5.70 & 6.74 & 2.05 & 0.131 & 3.90 & 5.0 & 2.6 & 92.4 \\
\hline & $15-30$ & 5.50 & 5.45 & 1.14 & 0.087 & 3.19 & 8.0 & 1.6 & 90.4 \\
\hline & $30-45$ & 4.90 & 3.84 & 0.61 & 0.043 & 2.20 & 11.0 & 1.0 & 88.0 \\
\hline \multirow[t]{3}{*}{$\mathbf{C}$} & $0-15$ & 5.80 & 13.07 & 1.69 & 0.131 & 17.5 & 5.0 & 2.1 & 92.9 \\
\hline & $15-30$ & 5.70 & 6.35 & 1.06 & 0.089 & 9.18 & 5.5 & 1.6 & 92.9 \\
\hline & $30-45$ & 5.50 & 5.37 & 0.82 & 0.061 & 3.51 & 8.0 & 1.1 & 90.9 \\
\hline \multirow[t]{3}{*}{ D } & $0-15$ & 5.51 & 5.51 & 1.47 & 0.124 & 6.54 & 5.0 & 2.1 & 92.9 \\
\hline & $15-30$ & 3.79 & 3.79 & 0.93 & 0.071 & 4.10 & 5.5 & 1.6 & 92.9 \\
\hline & $30-45$ & 3.54 & 3.54 & 0.64 & 0.042 & 2.15 & 8.0 & 1.1 & 90.9 \\
\hline \multirow[t]{4}{*}{$\mathbf{E}$} & $0-15$ & 4.90 & 7.31 & 1.47 & 0.123 & 4.62 & 6.0 & 3.1 & 90.9 \\
\hline & $15-30$ & 4.80 & 6.51 & 1.01 & 0.086 & 2.74 & 7.0 & 3.1 & 89.9 \\
\hline & $30-45$ & 4.70 & 4.91 & 0.88 & 0.051 & 2.07 & 9.0 & 2.6 & 88.4 \\
\hline & \multicolumn{9}{|c|}{ Mean+SD } \\
\hline \multicolumn{2}{|l|}{ Control Mean } & 5.40 & 4.89 & 1.118 & 0.123 & 3.40 & 7.48 & 1.30 & 91.67 \\
\hline \multicolumn{10}{|l|}{ Key: } \\
\hline & A & $=$ & Agbor & & & & & & \\
\hline & B & $=$ & Asaba & & & & & & \\
\hline & $\mathrm{C}$ & $=$ & Isele-U & wu & & & & & \\
\hline & D & $=$ & Okpana & & & & & & \\
\hline & $\mathrm{E}$ & $=$ & Onicha & Ugbo & & & & & \\
\hline
\end{tabular}

Soil pH: The $\mathrm{pH}$ values of the soil samples in all the sites ranged from 4.20 to 5.80 with mean value of $5.15 \pm 0.48$. This shows that the soils were moderately acidic. The values decreased with depth indicating that the acidity of the soils increased with depth. The $\mathrm{pH}$ values obtained in this study are in the same range with the values reported by Osakwe (2013), Osakwe (2014) Egbeda et al., (2015) but lower than those reported by Chaudhari (2013), Matthews-Amune and Kakulu (2013), Idugboe et al., (2014). Soil $\mathrm{pH}$ and other soil properties are especially important in soil processes responsible for solubility of heavy metals in soil and their transportation (Matthews - Amune and Kakukulu, 2012). At high $\mathrm{pH}$, metals tend to form metal mineral phosphates and carbonates which are insoluble while at low $\mathrm{pH}$ they tend to be found as free ionic species or as soluble organometals and are more bioavailable (Rensing and Maier, 2003; Hoffman, 2007; Egbeda et al., 2015). Since at low pH (acidic) metals are more soluble and more bioavailable in the soil solution, the range of $\mathrm{pH}$ values obtained in this study will favour plant uptake of heavy metal and hence toxicity problems are possible.

Total organic carbon (TOC): The total organic carbon in the soil samples from all the sites ranged from $(\%) 0.61$ to 2.08 with mean value of $1.20 \pm$ $0.13 \%$. The values obtained in this study are almost in the same range with those reported by Oviasogie and Omoruyi,(2007). These levels are however, by far lower than those reported by Tukura et al., (2007); Osenwota, (2009), Chaudhari, (2013) but higher than the values reported by Idugbose et al., (2014). According to Yun (2003), total organic carbon is a measure of organic content in soil and contributes significantly to the acidity of soil through organic acids and biological activities through the complexion of metals (Zoumis et al 2001). Nelson and Sommer observed that high total organic carbon content entails larger adsorption surfaces and more metals are adsorbed to organic material. Total organic carbon content obtained in this study may be attributed to vehicular discharge on the high way.

Total Nitrogen: Total Nitrogen (TN) ranged from (\%) 0.042 to 0.14 with mean value of $0.09 \pm 0.80 \%$. Similar range of values has been reported (Osakwe, 2009). Nitrogen can be introduced into the soils by natural processes such as lightening, decay of plant tissues (Eddy et al, 2006).

Phosphate: Phosphate values varied from $\left(\mathrm{mgkg}^{-1}\right) 1.93$ to 17.54 with mean value of $6.41 \pm$ 1.13. The values recorded in this study are higher than those reported by Iwegbue et al., (2006), Chaudhare (2013). Cassava tuber is a rich source of phosphorus (Jung et al, 2002), therefore the level of phosphate recorded in this study could be attributed to some decayed cassava tubers in the farmlands. According to Isirimah et al., 2003, phosphorus is essential for the seeds and development of fibrous root system in plants.

Electrical conductivity (EC): The electrical conductivity (EC) of the soil samples from al the sites 
ranged from $\left(\mu \mathrm{Scm}^{-1}\right) 3.54$ to 13.07 with mean value of $5.94 \pm 1.32$. The range of values obtained in this study is higher than that reported by Chaudhari et al., (2013), Egbenda et al., (2015) but lower than the values reported by Obasi et al., (2012), Badejo et al., (2013), Idugboe et al., (2014). These values indicate significant presence of trace metal ions or ionisable materials in the soil (Fuller et al., 1995, Egbenda et al., 2015).

Particle Size: $\quad$ For particle size distribution, sand size fraction was highest, followed by clay and then silt. These proportions show that the soils were coarse and as such have low supply of nutrients and moisture unlike fine textured soils that have sufficient water holding capacity, good aeration and high supply of nutrients (Wilde et al., 1972). The soils have low sorption capacity for ions due to their sandy texture.

Heavy Metals: Soil Samples; The concentrations of heavy metals in soils from all the sites are shown on Table 2.

Table 2: Concentration of heavy metals in all the sites $\left(\mathrm{mgkg}^{-1}\right)$

\begin{tabular}{|c|c|c|c|c|c|c|}
\hline Sample site & $\begin{array}{l}\text { Depth } \\
\text { (cm) }\end{array}$ & $\mathbf{F e}$ & Zn & $\mathrm{Cr}$ & $\mathbf{N i}$ & $\mathbf{P b}$ \\
\hline \multirow[t]{3}{*}{ A } & $0-15$ & 204.12 & 104.4 & 14.25 & 58.23 & 14.85 \\
\hline & $15-30$ & 170.24 & 67.30 & 10.54 & 38.42 & 12.14 \\
\hline & $30-45$ & 95.46 & 40.28 & 7.10 & 24.58 & 6.82 \\
\hline \multirow[t]{3}{*}{ B } & $0-15$ & 109.64 & 93.52 & 18.62 & 49.42 & 17.13 \\
\hline & $15-30$ & 138.23 & 58.21 & 13.10 & 25.62 & 13.74 \\
\hline & $30-45$ & 62.32 & 38.04 & 8.64 & 17.81 & 9.46 \\
\hline \multirow[t]{3}{*}{$\mathrm{C}$} & $0-15$ & 184.72 & 105.78 & 28.52 & 18.62 & 18.21 \\
\hline & $15-30$ & 146.81 & 56.12 & 16.48 & 13.42 & 14.43 \\
\hline & $30-45$ & 103.42 & 39.24 & 12.23 & 8.56 & 10.64 \\
\hline \multirow[t]{3}{*}{$\mathrm{D}$} & $0-15$ & 166.23 & 55.29 & 19.26 & 15.82 & 15.83 \\
\hline & $15-30$ & 146.22 & 42.45 & 15.47 & 9.62 & 10.56 \\
\hline & $30-45$ & 99.24 & 30.34 & 11.67 & 6.92 & 6.84 \\
\hline \multirow[t]{3}{*}{$\mathrm{E}$} & $0-15$ & 204.32 & 75.73 & 17.28 & 41.24 & 26.67 \\
\hline & $15-30$ & 173.68 & 51.87 & 12.24 & 30.23 & 19.42 \\
\hline & $30-45$ & 139.29 & 31.47 & 8.58 & 16.24 & 7.681 \\
\hline \multicolumn{2}{|l|}{ Mean+SD } & $142.93+42.16$ & $59.34 \pm 25.21$ & $14.27 \pm 5.39$ & $24.98+15.57$ & $13.63 \pm 5.41$ \\
\hline \multicolumn{2}{|c|}{ Control Mean } & $37 . \overline{8} 7$ & 8.72 & 0.88 & 0.28 & 0.103 \\
\hline
\end{tabular}

All the metals studied were detected in all the sites. Generally the concentrations of the metals were highest at the top soils. This is expected since the top soil is the point of contact. The metal levels in all the sites were significantly higher than the levels observed in the control sites.

Iron has the highest mean concentration among all the metals studied and its levels ranged from $\left(\mathrm{mgkg}^{-1}\right)$ 62.32 to 204.32 with mean value of $142.93 \pm 42.16$. High concentrations of iron in soils relative to other metals have been reported in various studies, confirming that natural soils contain significant levels of iron (Dara, 1993; Ademoroti, 1996; Aluko and Oluwande, 2003). The mean value of iron obtained in this study is lower than those reported by Osakwe, (2010); Nwachukwu et al., (2011); Idugboe et al., (2014), but higher than the values reported by Okorie and Egila (2012), Suleman, (2014).

Zinc concentrations $\left(\mathrm{mgkg}^{-1}\right)$ vary from 30.34 to 105.78 with mean value of $59.34 \pm 25.21$. Similar range of values was reported by Iwegbue et al., (2013). The range of values obtained in this study is lower than those reported by Zakir et al., (2014), Ojo et al., (2015); but higher than the levels reported by Nwachukwu et al., (2013), Ubwa et al., (2013). Zinc is also the second most abundant metal obtained in this study. This high level of zinc in roadside soil could be attributed to the wear and tear of vehicle bodies with galvanized steel surfaces (Zakir et al, 2014). Zinc is used in brake linings of vehicles because of its heat conducting properties and can be released during mechanical abrasion of vehicles and from combustion of engine oil and also from vehicle tyres (El-Gamal, 2000, Akbar et al., 2006; Manno et al., 2006, Matthews - Amune and Kakulu 2013). Elik, (2003) reported that high concentration of Zinc in heavy traffic zones indicate that fragmentation of car tyres is a likely sources of the metal. Other possible sources of zinc in relation to automobile traffic in addition to wearing of brake lining are losses of oil and cooling liquid of vehicles and wearing of road paved surface (Saeedi et al., 2009). The amount of zinc recorded at Issele-Ukwu was the highest probably because of the access road leading to many Aniocha towns and many vehicles move to and fro from the towns to the expressway.

Chromium concentrations ranged from $\left(\mathrm{mgkg}^{-1}\right) 8.52$ to 28.52 with a mean value of $14.27 \pm 5.39$. These values are higher than those reported by Okoye and Egila (2012); Iwegbue et al., (2013); Ubwa et al., (2013), Idugbose et al., (2014); but lower than the values reported by Ferronato et al., (2013); Zakir et al., (2014). According to Al-Rhashman (2007), chromium level in road side soil is associated with the chromic plating of some vehicle parts used for 
preservation of corrosion. Chromium is carcinogenic resulting in cancer of respiratory organs in workers exposed to chromium containing dust (Langard, 1980).

Lead levels in all the sites were in the range of $\left(\mathrm{mgkg}^{-1}\right) 6.82$ to 26.67 with mean value of $13.63 \pm$ 5.41. Similar range of values for lead has been reported (Zakir, et al., 2014; Das et al; 2015). However the lead levels observed in this study are significantly higher than those reported by MatthewsAmune (2013), Ubwa et al., (2013) and lower than those of other similar studies (Nwachukwu et al., 2011; Najib et al., 2012; Pam et al., 2013). The concentration of lead in the soil is likely to have derived from vehicle exhaust fumes containing some lead-rich aerosols. (Zakir et al., 2014). Studies have shown that the use of tetraethyl lead as an antiknocking agent in gasoline gives rise to its release during emissions from automobiles and fossil fuel combustion (Oztas and Ata, 2002, Akbar et al., 2006, Onder et al., 2007, Sharma and Parasade, 2010). Sherene (2010) reported that major sources of lead pollution are exhaust gases of petrol engines, which account for nearly $80 \%$ of the total lead in the air. Kakulu, (2003) also reported that lead content of leaded gasoline in Nigeria ranges from 0.60 to $0.80 \mathrm{~g} / \mathrm{l}$. In addition, lead levels in roadside can also be attributed to wearing down of vehicle breaklinings and tyres (Sharma and Prasade 2010, Zhang et al., 2012), Soerme and Langerkvsith, 2002). Elevated levels of lead constitute serious health risk. Purefoy, (2010) reported several deaths in a village in Zamfara State, Nigeria as a result of lead poisoning. Sometime this year similar situation occurred in the same State claiming the life of about twenty eight children resulting from lead poisoning.

The concentrations of nickel in the soils from all the sites ranged from $\left(\mathrm{mgkg}^{-1}\right) 6.92$ to 58.23 with a mean value of $24.98 \pm 15.57$. The mean value of nickel

obtained in this study is consistent with the values reported by Najeb et al., (2012), Ogundiran and Osibanjo, (2009); Oguntimehin and Ipinmoroti, 2007), Nwachukwu et al., 2013). The mean level of nickel obtained in this study is however higher than that reported by Pam, et al., (2013); Matthews Amune and Kakulu, 2013; Ubwa et al, (2013). Airborne particles emitted by brakes and wears from vehicle tyres can contain considerable amounts of nickel (Onder et al., 2007). This is a probable source of nickel in the recorded soils. Anthropogenic imput of nickel in the study areas could also be from the diesel used in the automobiles (Iwegbue, 2013). Exposure to intake of large amount of nickel from plants, grown on nickel rich soil leads to higher chances of developing cancer of the lungs, nose, larynx and prostrate as well as respiratory failures, birth defects and heart disorders (Duda-Chodale and Blaszezyk, 2008; Lentech, 2009).

Cassava Samples: All the metals studied. were detected in the cassava leaves except nickel, and also cassava tubers except nickel and lead. Plants are known to take up and accumulate metals from contaminated soils (Kasheem and Abdul Singh, 1999), hence their detection in the cassava tubers and leaves is not surprising.

The mean concentrations of heavy metals in cassava leaves and tubers from all the sites are presented on Tables 3 and 4 respectively.

Table 3: The mean concentrations of $\mathrm{Fe}, \mathrm{Zn}, \mathrm{Cr}, \mathrm{Pb}$ and $\mathrm{Ni}$ in cassava leaves. $\left(\mathrm{mgkg}^{-1}\right)$

\begin{tabular}{llllll}
\hline Sample Site & $\mathrm{Fe}$ & $\mathrm{Zn}$ & $\mathrm{Cr}$ & $\mathrm{Pb}$ & $\mathrm{Ni}$ \\
\hline $\mathbf{A}$ & 13.93 & 1.88 & 0.81 & $\mathrm{ND}$ & $\mathrm{ND}$ \\
$\mathbf{B}$ & 12.73 & 0.91 & 0.24 & $\mathrm{ND}$ & $\mathrm{ND}$ \\
$\mathbf{C}$ & 6.58 & 0.86 & 0.49 & $\mathrm{ND}$ & $\mathrm{ND}$ \\
$\mathbf{D}$ & 8.63 & 1.26 & 0.33 & $\mathrm{ND}$ & $\mathrm{ND}$ \\
$\mathbf{E}$ & 6.24 & 0.84 & 1.79 & $\mathrm{ND}$ & $\mathrm{ND}$ \\
Control Mean & 5.20 & 0.74 & 0.26 & $\mathrm{ND}$ & $\mathrm{ND}$ \\
\hline
\end{tabular}

Table 4: The mean concentrations of the metals in cassava tubers $\left(\mathrm{mg} / \mathrm{kg}^{-1}\right)$

\begin{tabular}{llllcc}
\hline \multicolumn{1}{c}{ Sample site } & Fe & Zn & Cr & Pb & Ni \\
\hline A & 16.49 & 2.93 & 1.46 & 1.67 & ND \\
B & 21.96 & 4.92 & 4.23 & 5.57 & ND \\
C & 22.39 & 4.70 & 5.36 & 4.27 & ND \\
D & 21.53 & 3.19 & 5.55 & 2.19 & ND \\
E & 26.15 & 5.02 & 9.10 & 3.59 & ND \\
Mean \pm SD & $21.70 \pm 3.45$ & $4.15 \pm 1.01$ & $5.12 \pm 2.75$ & $3.46 \pm 1.58$ & ND \\
Control Mean & 15.18 & 3.20 & 2.89 & 1.93 & ND \\
\hline
\end{tabular}

The mean values of all the metals obtained in this study in the cassava leaves and tubers are significantly higher than the mean values recorded in the control samples indicating some heavy metal enrichments on the vegetation as a result of traffic activities. Nickel and lead were similarly not detected by Akaniwor et al, (2005) in raw and processed Nigerian staple foods from oil producing areas of Rivers and Bayelsa States of Nigeria.
The mean values observed in the leaves and tubers respectively were $\left(\mathrm{mgkg}^{-1}\right) 21.70 \pm 3.45$ and $9.62 \pm$ 3.53 for $\mathrm{Fe}, 4.15 \pm 1.01$ and $1.15 \pm 0.44$ for $\mathrm{Zn}, 5.12$ \pm 2.75 and $0.37 \pm 0.63$ for $\mathrm{Cr}, 3.46 \pm 1.58$ for $\mathrm{Pb}$ only in leaves. The general trend is that the metal levels were higher in the leaf samples than in the tuber samples. Similar observation has been reported (Ano et al, 2007, Nabulo, 2006, Osakwe, 2009). The concentrations of all the metals obtained are higher than those reported for cassava plants grown around 
some oil flaring zones by Osaobhien and Otuya (2006), and for stem bark of Moringa olei fera lam, by Gupta et al., (2014) but lower than those reported by Osakwe, (2009) on cassava plants grown along Warri - Abraka expressway and also the values reported by Abidemi (2013) in vegetation from an industrial area. The higher levels of these metals in leaves than in tubers could be attributed to the fact that leaves in addition to the metals translocated from the soils also have aerial foliage enrichment or folier absorption from the surrounding air. There could also be some loss of metals from the soil through leaching. It is worthy to note that the levels of heavy metals obtained in the cassava plants are below FAO/WHO guidelines for metals in food and vegetables. (FAO/WHO 1976). The FAO/WHO guidelines for metals in foods and vegetables are shown on table 5 .

Table 5: FAO/WHO guidelines for metals in foods and vegetation

\begin{tabular}{|c|c|c|c|c|}
\hline $\begin{array}{l}\text { Metals } \\
(\mathrm{mgkg})\end{array}$ & FAO/WHO & NAFDAC & EC/CODEX & $\begin{array}{l}\text { NORMAL RANGE IN } \\
\text { PLANT }\end{array}$ \\
\hline $\mathrm{Cd}$ & 1 & - & 0.2 & $<4$ \\
\hline $\mathrm{Cu}$ & 30 & 20 & 0.3 & 2.5 \\
\hline $\mathrm{Pb}$ & 2 & 2 & 0.3 & $0.50-30$ \\
\hline $\mathrm{Zn}$ & 60 & 50 & $<50$ & $20-100$ \\
\hline $\mathrm{Fe}$ & 48 & - & - & $400-500$ \\
\hline $\mathrm{Ni}$ & - & - & - & $0.20-50$ \\
\hline
\end{tabular}

Source: FAO/WHO, (1976)

Green plants use iron for energy transformation processes so its deficiency in plants leads to growth problems (Lenntech, 2012). Lead is highly hazardous for plants, animals and microorganisms (Suleiman, 2014).

Plant Concentration Factor (PCF): Studies have shown that plants grown on heavy metal polluted soils possess enhanced metal concentration (Grant and Dobbs, 1977) and the uptake of metal ions has been shown to be influenced by the metal species and plant parts (Juste and Mench, 1992). Based on this, plant concentration factor (PCF) was computed using the following equation (Liang et al., 2011).

$P C F=\frac{\text { Cplant }}{\text { Csoil }}$

Where Cplant $=$ metal concentrations in plant

Csoil $=$ metal concentrations in soils

The values indicate the levels of metals in the edible parts of the plant as a fraction of the total metal concentration in the soil and this soil-to-plant factor is one of the key components of human exposure to metals through the food chain. The values obtained for the metals in all the sites are presented on table 6 .

Table 6: Plant concentration factor (PCF) of the heavy metals in the cassava samples.

\begin{tabular}{cccccc}
\hline Site & Fe & $\mathbf{Z n}$ & $\mathbf{C r}$ & $\mathbf{N i}$ & $\mathbf{P b}$ \\
\hline A & 0.194 & 0.068 & 0.213 & 0.000 & 0.148 \\
B & 0.334 & 0.092 & 0.332 & 0.000 & 0.414 \\
C & 0.199 & 0.083 & 0.307 & 0.000 & 0.296 \\
D & 0.219 & 0.104 & 0.373 & 0.000 & 0.198 \\
E & 0.188 & 0.110 & 0.857 & 0.000 & 0.200 \\
\hline
\end{tabular}

The plant concentration factor which is also called plant transfer ratio values obtained in this study are almost in the some range with those reported by
Osakwe, (2009); Liang et al; 2011) Opaluwa et al., (2012). For all the sites, the soil plant transfer values were in the order $\mathrm{Cr}>\mathrm{Pb}>\mathrm{Fe}>\mathrm{Zn}>\mathrm{Ni}$. This shows that among all the metals studied chromium is easiest to migrate. This trend signifies that plant absorbs a higher concentration of $\mathrm{Cr}$ from the soil compared to other metals while $\mathrm{Ni}$ is the least absorbed. Abedemi, (2013) similarly reported that $\mathrm{Cr}$ had highest value of plant transfer ratio among all the metals in his study and also more easily available for plant uptake. Soil electrolyte plays an important role in the process of heavy metal transfer, and influences transformation ability of heavy metals. The range of values recorded in this study indicates that all the metals fall into the category of elements showing medium accumulation (0.01-1.0) except for $\mathrm{Ni}$ which fell into the category of elements lacking accumulation Kabata Pendias and Pendias (1992).

Conclusion : The results obtained from the physicochemical analysis of the soil samples revealed that the roadside soils were moderately acidic and contained significant amounts of organic matters and some ionisable inorganic substances. The heavy metal analysis confirms heavy metal enrichment in the soils and cassava plants as a result of automobile exhaust emissions along the expressway. Although the plant concentration factor values indicate medium accumulation for the cassava food crops, further exposure of the farmlands to the traffic emission for a very long time may result to a high level of pollution of the soils and food crops which will eventually constitute serious health risks to humans. To minimise such health risks, farmlands should be located far away from busy expressways.

\section{REFERENCES}


Abdul Kasheem, M.D. and Singh, B. (1999). Heavy metal contamination of soil and vegetation in the vicinity of industries in Bangladesh - Water, air and soil Pollution. Contamination of Vegetables in Delhi. Executive Summary of Technical Report 115: $347-361$

Abidemi, O.O. (2013). Accumulation and contamination of heavy metals in soil and vegetation from industrial area of Ikinun, Osun State, Nigeria. Global Journal of Pure and Applied Chemistry Research. 1 (1) 25-34

Ademoroti, C.M.A. (1996). Environmental Chemistry and Toxicology. Foludex Press Ltd Ibadan, 150-188

Adriano, D.C. (2001). Trace Elements in Terrestrial Environment $\left(2^{\text {nd }}\right.$ edition) springer-Verlay company, New York

Akaniwor, J.O., Onyeke, E.N. and Ifemeje, J.C. (2005). Trace metal levels in raw and heat processed Nigerian staple foods from oil producing areas of Rivers and Bayelsa States. Journal of Applied Sciences and Environmental Management 10(2) : 23-27.

Akbar, N.F., Hale, W.H.G., Headley, A.D. and Athar, M. (2000). Heavy metal contamination of roadside soils. Soil and Water Research 1(4), 158-163.

Al-Kashman, O.A. (2007). The investigation of metal concentrations in street dust samples in Aqaba city, Jordan. Environmental Geochemistry and Health. 29(3) 197-207

Al-Khashman, O.A (2012). Assessment of Heavy Metal Accumulation in urban soil Around Potash Industrial Site in the East of the Dead sea and their Environmental Risks. Soil and Sediment Contamination, 21:276-290

Aluko, O.O. (2001). Characterization and Treatment of leachates from a Municipal Solid Waste landfill site in Ibadan. Mphil Dissertation, University of Ibadan, Ibadan, Nigeria, 83-84

Aluko, O.O. and Oluwande, P.A. (2003). Characterization of leachates from a municipal solid waste landfill site in Ibadan, Nigeria. Journal of Environmental Health Research, 2: $83-84$

Ano, A.O., Odoemena, S.A. and Ekwueme, P.O. (2007) lead and cadmium levels soils and cassava (manihot esculenta grantz) along Enugu - Portharcourt Expressway in Nigeria.
Electronic Journal of Environmental, Agricultural and Food Chemistry 6(5) 2024-2031

Ayodele, T.T. and Gaya, U.M. (1994) determination of lead in street dust to index its pollution in Kano Municipal spectrum Journal 1, 92-95.

Badejo, A.A., Taiwo, A.O., Adekunle, A.A. and Bada, B.S. (2013). Spatio-temporal levels of essential trace metals around municipal solid waste dumpsite sin Abeokuta, Nigeria. Pacific Journal of Science and Technology, 14(2) 682692

Bouyoucos, G.J. (1962). Improved Hydrometer method for making particle size analysis. Agronomy Journal, 54:465-465

Bray, R.H. and Kurtz, L.T. (1945). Determination of Total organic and Available Phosphorus in soils. Soil Science, 59:30-45

Bremner, J.M. (1965). Total Nitrogen. In: Black, C.A (ed) Methods of Soil Analysis part 2. Agronomy, 9:149-178

Burreell, D.C. (1974). Atomic spectrometric analysis of Heavy metals in Water. Ann Arbor, Michigan, 19-32

Chaudheri, K.G. (2013). Studies of physicochemical parameters of soil samples. Advances in applied Sciences Research, 4(6) 246-248

Chopra, G. And Kanzar, C. (1988). ANALYTICAL AGRICULTURAL CHEMistry. $2^{\text {nd }}$ Edition Prentice - hall, India

Dara, S.S. (1993). A textbook of environmental and pollution control, S. Chand and Company Ltd. Ram Naga, New Delhi, 110055

Davey, B.J and Conyers, M.K. (1988). Determination of $\mathrm{pH}$ of acid soils. Soil Science, 146:141-150

Djingova, r., Kuleff, I. And Andreev, N. (1993). Comparison of the ability of several vascular plants to reflect environmental pollution. Chemosphere, 27:1385-1396

Eddy, N.O., Odoemelem, S.A. and Mbaba, A. (2006) Elemental composition of osil in some dumpsites. Electronic Journal of Environmental Agricultural and Food Chemistry 5(3), 10151031

Egbenda, P.O., Thullah, F. And kamara, I. (2015). A physicochemical analysis of soil and selected fruits in one rehabilitated mined out site in the Sierra Rutile environs for the presence of heavy metals: Lead, Copper, Zinc, Chromium and 
Arsenic. African Journal of Pure and Applied chemistry 9(2) 27-32

El - Gamal, I.M (2000). Distribution pattern of some heavy metals in soil and plants along elMoukattam highway, Egypt. ICEHM: 518-524.

Elike, A. (2003). Heavy Metal accumulation in street dust samples in Sivas. Communication, in soil Science and plant analysis, 34, 145-156

FAO/WHO (1976). List of maximum levels recommended for contaminants by the joint FAO/WHO condex. Alimentarias commission $2^{\text {nd }}$ Series, CAC/FAL, 3: 1-8

Ferronato, C., Antisari, L.V., Modesto, M. And Vianello, G. (2013). Speciation of heavy metals at water sediment interface. Environmental Quality, 10:51-64

Fuller, M.A., Feamebough, W., Mitchel, D. And Trueman, I.C (1995). Desert reclamation using yellow river irrigation watr in Ningxia, china. Soil use and Management 11:77-83

Grant, C. And Dobbs, A.J. (1977). The growth and metal contents of plants grown in soil contaminated by a copper chrome arsenic wood preservative. Environmental Pollution, 14, 213 226

Gupta, J., Gupta, A. Gupta, A.K. (2014). Determination of trace metals in the stem bark of Moringa Oleifera Lam. International Journal of Chemical Studies, 2 (4): 39-42

Hutton, M. And Symon, C. (1986). The Quantities of Cadmium, Lead, Mercury and Arsenic entering the U.K. Environment from human activities Science of the Total environment, 57: 129-150

Idugboe, S.O., Tawari-Fufeyin, P. And Midonu, A.A (2014). Soil pollution in two auto mechanic villages in Benin city, Nigeria. IOSR Journal of Environmental Science Toxicology and Food Technology 8(I Ver V) 9-14

Isirimah, W.O., Dickson A.A and Igwe, C. (2003). Introduction to soil Chemistry and Biology for Agricultural and biotechnology. Osia International Publishers Ltd. Port Harcourt, 5-8

Iwegbue, C.M.A, Bassey, F.I, Tesi, G.O., Nwajei, G.E. and Tsafe, A.I. (2013). Assessment of Heavy Metal Contamination In soils around cassava processing Mills in Sub-urban Areas of Delta State, Southern Nigeria. Nigeria Journal of Basic and Applied Sciences, 21(2):96-104
Iwegbue, C.M.A., Isirimah, N.O. Igwe, C. And Walham, E.S. (2006). Characteristic levels of Heavy Metals in soil Profiles of Automobile Mechanic Waste Dumps in Nigeria. Environmentalist, 26, 131-137

Jip. A.S.R (1979). Selected methods for soil and plant analysis. International Institute of Tropical Agriculture manual 1:205-211

Jung, G.B., Kim, W.I., Moon, K.K and Ryu, I.S. (2002). Fractionation and availability of heavy metals in paddy soils near abandoned mining areas (Korea). Journal of Enor Agricultural 19(4), 319-323

Juste, C. And Mench, M. (1992). Long term application of sewage sludge and its effects on metal uptake by crops. In: biogeochemistry of Trace Metals. Adriano, D.C (ed) C.R.C Press. Bocaraton, 159-194

Kakulu, S.E (2003). Trace metal concentration in roadside surface soil and tree barks. A measurement of local atmosphere pollution in Abuja, Nigeria. Environmental Monitoring Assessment 89:233-242.

Langard, S. (1980). Metals in the Environment. Chapter 4, in Wajdron, H.A (ed.), Academic press, London

Langard, S. (1980). Metals in the environment chapter 4 In: Wajdron, H.A (ed.) Academic Press, London

Lenntech, B.V (2012). Heavy metals. Available http:/www. Lenntech com.pt/processes/pesadol heavy-metals. Htm

Manno, E., Varrica, d. And Dongarra, G. (2006). Metal Distribution in Road dust samples collected in an urban area close to a petrochemical plant at Gela, Sicily. Atmosphere Environment, 40:5929-5941

Matthews -Amune, O.C and Kakulu, S. (2013). Investigation of heavy metal levels in road-side agricultural soil and plant samples in Adogo, Nigeria, Academic Journal of Environmental Sciences 1 (2) 31-35

Mtunzi, F.M., Dikio, E.D and Moja, S.J. (2015). Evaluation of heavy metal Pollution on soil in Vaderbijlpark, South Africa. International Journal of Environmental Monitoring and analysis, 3(2): 44-49

Nabulo, G., Oryem-Origa, $\mathrm{H}$ and Diamond, $\mathrm{M}$. (2006) Assessment of lead, cadmium and zinc 
contamination of roadside soils, surface films and vegetables in Kampala city, Uganda. Environment Research, 101, 43-52

Najib, N.W.A.Z., Mohammed, s.a., Ismail, S.A., and Ahmad, W.A.A.W. (2012). Assessment of Heavy Metal in soil due to Human Activities in Kangar, Perlis, Malaysia

Nelson, D.W. and Sommers, L.E (1982). Total Organic Carbon and Organic Matter. In: Methods of soil analysis. In: Page A.Z. (ed), 539-571

Nwachukwu, M.A, Ntesat B and Mbaneme, F.C. (2013). Assessment of direct soil pollution in automobile junk market. Journal of Environmental Chemistry and Ecotoxicology

Nwachukwu, M.A., Feng, H. And Alinnor, J. (2011). Trace Metal Dispersion in soil from Automechanica Village to urban Residential Areas in Owerri, Nigeria. Procedia Environmental Sciences 4, 310-322

Obasi, N.A., Akubugwo, O.C; Ugbogu, O.C and Otuchristian, G. (2013). Assessment of physicochemical properties and heavy metals availability in dumpsites along Enugu Port Harcourt expressways, South East Nigeria, Asian Journal of applied Sciences 5:342-356

Okorie, E.O. and Egila, J.N. (2012). Distribution of metal sin an abandoned coal mine overburden soil from Okaba, Kogi State, Nigeria. Journal of Chemical Society of Nigeria, 37(2): 41-53

Onder, S., Dursun, S., Gezgin, S. And Demirbas, A. (2007). Determination of heavy metal pollution in grass and soil of city centre green areas Konya, Turkey, Polish Journal of Environmental Study. 16 (1) 145-154

Onianwa, P.C. and Fakayode, S.O. (2000). Lead contamination of topsoil and vegetation in the vicinity of a battery factory in Ibadan. Environmental Geochemistry and Health 22: 211-218

Opaluwa, O.D., Aremu, M.O. Ogbo, L.O., Abiola, K.A., Odiba, I.E., Abubkar, M.M and Nweze, N.O. (2012). Heavy metal concentrations in soils, plant leaves and crops ground around dumpsites in Lafia Metropolis, Nassarawa State, Nigeria. Advances in Applied Science Research, $3(2): 780-784$

Osabohien, E. And Otuya, O.B. (2006). Heavy metals in soils, tubers and leaves of cassava (Manihot utilisma) plants grown around some oil-spill and gas flaring zones in Delta State,
Nigeria. European Journal of Scientific Research 13(1) 53-57

Osakwe, S.A (2009). Heavy Metal distribution and bioavailability in soils and Cassava (Manihot esculenta grantz) along Warri-Abraka Expressway, Delta State, Nigeria. Journal of Chemical Society of Nigeria, 34(1): 211-217

Osakwe, S.A. (2010). Chemical speciation and mobility of some heavy metals in soils around automobile waste dumpsites in Northern part of Niger Delta, South Central Nigeria, Journal of Applied Science and Environmental Management, 14(4) 13-130

Osakwe, S.A (2013): Assessment of the effects of wood processing industries in selected parts of Delta State, Nigeria on the soils and vegetation in their vicinities. IOSR Journal of Applied Chemistry 3:22-30

Osakwe, S.A. (2014). Heavy metal contamination and physicochemical characteristics of soils from automobile workshops in Abraka, Delta State, Nigeria International Journal of Natural Science Research 2(4) 48-58.

Osemwota, O.I. (2009). Effect of abattoir effluent on the physical and chemical properties of soils. Environmental Monitoring Assessment, 10581064

Oviasogie, P.O and Omoruyi, E. (2007), levels of heavy metals and physicochemical properties of soil in a foam manufacturing industry. Journal of Chemical Society of Nigeria, 32(1) 102-106.

Oztas, T. And Sibel, A.S. (2002). Distribution patterns of lead accumulation in roadside soils: a case study from Erzurum. Turkey. International Journal of Environmental Pollution 18(2): 190196

Pam, A.A., Ato, R.S and Offem, J.O (2013), Contribution of Automobile Mechanic Sites to Heavy Metals in Soil: A case study of North Bank Mechanic village, Makurdi, Benue State, Central Nigeria. Journal of Chemical, Biological and Physical Sciences 3(3) 2337-2347

Qasem, M.J. and Kamal, A.M. (1999). Contamination of roadside soil, plants and air with heavy metal sin Jordan a comparative study. Turkish Journal of Chemistry 23, 209-220

Saeedi, M, Hosseinzadeh, M., Jamshidi, A, and Pajooheshfar, S.P. (2009). Assessment of heavy metals contamination and leaching characteristics in high way side soils, Iran. 
Environmental Monitoring Assessment 151 (1/4), 231-241

Sharma, S. And Parasade, F.M. (2010). Accumulation of lead and cadmium in soil and vegetable crops along major highways in Agra, India. Journal of Chemistry 7(4)1174-1183

Sherene, T. (2010). Mobility and transport of heavy metals in polluted soil environment. Biological forum - an International Journal, 2(2): 112-121

Suleiman, F.B (2014). Trace metal contents in the leaves of Cassia Occidentalis Linn from some selected sites in Katsina, Nigeria. IOSR Journal of Applied Chemistry (IOSR-JAC) 7(6 Ver 1 ) 37

Tukura, B.W., kagbu, J.A and Gimba, C.E. (2007). Effects of $\mathrm{pH}$ and total organic carbon (TOC) on the distribution of trace metals in Kubanni dam sediments, Zaria, Nigeria, Science World Journal $2(3): 1-6$

Ubwa, S.T., Atoo, G.H., Offem, J.O., Abah, J and Asemave, K. (2013). Effect of Activities at Gboko Abattoir on some Physical Properties and Heavy Metals levels of surrounding soil. International Journal of Chemistry, 5(1) 49-57
Wilde, S.A., Weight, G.K. and Ixer, J.G (1972). Soil and Plant Analysis for the Culture. New Delhi, Oxford B.H. Publication Company, 172

Yan, O. (2003). Simulating dynamic load of naturally occurring TOC from watershed. Water Research, 37:823-832

Zakir, H.M., Sultana, N. And Akter, M. (2014). Heavy Metal contamination in Roadside soils and Grasses: A case study from Ahaka City, Bangladest. Journal of Chemical, Biological and Physical Sciences. 4(2) 1661-1673

Zhang, F., Yan, X., Zeng, C., Zhang, M. Shrestha, S., Devkota, L.P. and Yao, T. (2012). Influence of traffic activity on heavy metal concentrations of roadside farmland soil in mountainous areas. International Journal of Environmental Research and Public Health, 9(5):1715-1731 